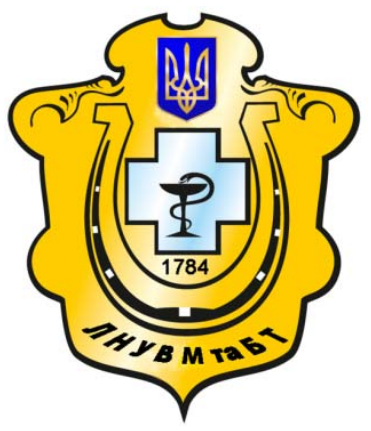

Науковий вісник Львівського національного університету ветеринарної медицини та біотехнологій імені С.3. Гжицького

Scientific Messenger of Lviv National University of Veterinary Medicine and Biotechnologies named after S.Z. Gzhytskyj

doi:10.15421/nvlvet7322

ISSN 2518-7554 print

ISSN 2518-1327 online

$\underline{\text { http://nvlvet.com.ua/ }}$

УДК 619.615.637.657

\title{
Дослідження гострої та хронічної токсичності експериментального препарату «Феросел Т»
}

\author{
В.Б. Тодорюк, В.М. Гунчак, Д.Ф. Гуфрій, Б.В. Гутий, І.І. Харів, Р.І. Хомик, Р.О. Васів, Н.М. Слободюк, \\ А.В. Винярська, О.Ю. Журавльов, П.Т. Гусар, Н.В. Назарук, Н.Я. Назарук, М.П. Солтис \\ tvb@vemman.com.ua; bvh@ukr.net
}

\begin{abstract}
Львівський наџіональний університет ветеринарної медицини та біотехнологій імені С.3. Гжиџького, вул. Пекарська, 50, м. Львів, 79010, Украӥна;
\end{abstract}

\begin{abstract}
У статті наведені результати гострої та хронічної токсичності нового феродекстранового препарату «Феросел Т》, який у своєму складі містить ферум і селен. Встановлено, щьо препарат «Феросел Т» в профілактичній $і$ терапевтичній дозах та в дозі в 3 рази більшої за терапевтичну, за перорального введення лабораторним шурам 3 доби поспіль не проявляв токсичної дії. За умов підикірного введення препарату загибелі білих шурів не було, лише встановлено короткочасне пригнічення лабораторних тварин, яким задавали препарат у дозі 10 мл/кг м.т. Встановлено, що в профілактичній $і$ оптимальній терапевтичній дозах препарат не впливав на детоксикаційну функиію печінки. У щурів, яким феросел Т вводили в максимальній терапевтичній та можливо токсичній дозах, тривалість гексеналового сну була на 32 i $35 \%$ більшою відносно контрольних величин. Токсичність фероселу Т також вивчали за показниками подразнювальної дії (за шкірною та кон'юктивальною пробами), алергізуючої дї (метод аплікації на шкіру) та визначали коефіцієнти маси внутрішніх органів за тривалого введення препарату.

У тварин, яким вводили феросел Т у дозі 10 мл/кг протягом 21 доби, дещо знижувалася рухова активність. Дослідження емоиійно-поведінкових реакцій лабораторних тварин після введення фероселу Т протягом 21 доби у терапевтичній та максимально терапевтичній дозах не показало істотного впливу на нервову систему. За показниками гіперемії і набряку шкіри та товщчини шкірної складки феросел Т в профілактичній та терапевтичних дозах при аплікації на шкіру кролів не спричиняв місцевої подразнювальної дії. Роздільна ін'єкиія препарату «Феросел Т» субплантарно морським свинкам по 0,1 мл не викликала набряклої реакції лап. У результаті проведених досліджень не виявлено алергенних властивостей у препарата «Феросел Т》.

У лабораторних щурів, яким вводили феросел Т в профілактичній дозі вірогідних змін коефіцієнтів маси серия, печінки, селезінки і нирок не встановлено. У щурів, яким вводили феросел Т в оптимальній терапевтичній дозі, у порівнянні з контрольними маса селезінки і печінки була відповідно на 10,3 і 6,4\% більшою. При введенні фероселу Т у максимально терапевтичній дозі маса селезінки і печінки була відповідно на 14,0 і 15,0\% більшою.

Одержані результати досліджень вказують про те, щзо препарат «Феросел T» є безпечним при застосуванні для профілактики і лікування тварин

Ключові слова: фармакологія, токсикологія, феросел T, Ферум, Селен, щурі, кролики, морські свинки
\end{abstract}

\section{Исследования острой и хронической токсичности экспериментального препарата «Феросел Т»}

В.Б. Тодорюк, В.М. Гунчак, Д.Ф. Гуфрий, Б.В. Гутый, И.И. Харив, Р.И. Хомик, Р.О. Васив, Н.М. Слободюк, А.В. Винярска, А.Ю. Журавлев, П.Т. Гусар, Н.В. Назарук, Н.Я. Назарук, М.П. Солтис tvb@vemman.com.ua; bvh@ukr.net

Львовский национальный университет ветеринарной медицины и биотехнологий имени С.3. Гжицкого, ул. Пекарская, 50, г. Львов, 79010, Украина;

Citation:

Todoriuk, V., Hunchak, V., Gufrij, D., Gutyj, B., Hariv, I., Khomyk, R., Vasiv, R., Slobodyuk, N., Vynyarska, A., Zhuravlov, O., Husar, P., Nazaruk, N.V., Nazaruk, N.Y., Soltis, M. (2017). Research of sharp and chronic toxicness of experimental preparation of «Ferosel T». Scientific Messenger LNUVMBT named after S.Z. Gzhytskyj, 19(73), 104-111. 
В статье приведены результаты острой и хронической токсичности нового феродекстранового препарата «Феросел $T$ 》, который в своем составе содержит Ферум и Селен. Установлено, что препарат «Феросел Т» в профилактической и терапевтической дозах и в дозе в 3 раза большей за терапевтическую, за перорального введения лабораторным крысам 3 сутки подряд ни проявлял токсического действия. В условиях подкожного введения препарата гибели бельх крыс не было, только установлено кратковременное угнетение лабораторных животных, которым задавали препарат в дозе 10 мл/кг м.ж. Установлено, что в профилактической и оптимальной терапевтической дозах не влиял на детоксикационную функизю печени. У крыс, которым феросел Т вводили в максимальной терапевтической и возможно токсической дозах, продолжительность гексеналового сна была на 32 и 35\% больше относительно контрольных величин. Токсичность феросела T также изучали по показателям раздражающего действия (по кожной и конъюнктивальной пробами), аллергизирующего действия (метод аппликации на кожу) и определяли коэффициенты массы внутренних органов при длительном введения npenapama.

У животных, которым вводили феросел Т в дозе 10 мл/кг в течение 21 суток, несколько снижалась двигательная активность. Исследование эмоционально-поведенческих реакиий лабораторных жсвотных после введения феросела Т течение 21 суток в терапевтической и максимально терапевтической дозах не показало существенного влияния на нервную систему. По показателям гиперемии и отека кожи и толщины кожной складки феросел Т в профилактической и терапевтических дозах при аппликации на кожу кроликов не вызывало местной раздражающего действия. Разделение инъекиия препарата «Феросел Т》 субплантарно морским свинкам по 0,1 мл не вызывала отечной реакции лап. В результате проведенных исследований не выявлено аллергенных свойств у препарата «Феросел Т».

У лабораторных крыс, которым вводили феросел Т в профилактической дозе возможных изменений коэффициентов массы сердца, печени, селезенки и почек не установлено. У крыс, которым вводили феросел Т в оптимальной терапевтической дозе, по сравнению с контрольными, масса селезенки и печени была соответственно на 10,3 и 6,4\% больше. При введении феросела Т в максимально терапевтической дозе масса селезенки и печени была соответственно на $14,0 \%$ и 15,0\% больие.

Полученные результаты исследований указывают о том, что препарат «Феросел Т» является безопасным при применении для профилактики и лечения животных

Ключевые слова: фармакология, токсикология, феросел T, железо, Селен, крысы, кролики, морские свинки

\title{
Research of sharp and chronic toxicness of experimental preparation of «Ferosel $T »$
}

\author{
V. Todoriuk, V. Hunchak, D. Gufrij, B. Gutyj, I. Hariv, R. Khomyk, R. Vasiv, N. Slobodyuk, A. Vynyarska, \\ O. Zhuravlov, P. Husar, N.V. Nazaruk, N.Y. Nazaruk, M. Soltis \\ tvb@vemman.com.ua; bvh@ukr.net
}

Lviv National University of Veterinary Medicine and Biotechnologies named after S.Z. Gzhytskyj,
Pekarska Str., 50, Lviv, 79010, Ukraine

\begin{abstract}
In the article the brought results over of sharp and chronic toxicness of new preparation dextran of iron "Ferosel T», that in the composition contains Iron and Selenium. It was set that preparation of «Ferosel T» in prophylactic and therapeutic doses and in a dose in 3 times of any more than therapeutic, at peroral introduction a 3 twenty-four hours in succession did not show a toxic action laboratory rats. At the terms of hypodermic introduction of preparation the death of white rats it was not, it is only set brief oppression of laboratory animals, animals preparations were given that in a dose $10 \mathrm{ml} / \mathrm{kg}$. It is set that in prophylactic and optimal therapeutic doses preparation did not influence on the detoxication function of liver. For rats, what was entered Ferosel $T$ in maximal therapeutic and maybe toxic doses, duration of a dream from Hexenalum was on 32 and 35 percents more relation than control sizes.
\end{abstract}

The toxicness of Ferosel $T$ was also studied on the indexes of irritating action(after dermic test and testis on conjunctiva), action of allergy (a method of applique on a skin) and determined the coefficients of mass of internalss at great while of introduction of preparation. For animals Ferosel $T$ was entered that in a dose $10 \mathrm{ml} / \mathrm{kg}$ during a 21 twenty-four hours, motive activity some went down. Research of emotional and behavior reactions of laboratory animals after introduction of Ferosel $T$ during a 21 twenty-four hours in therapeutic and maximally therapeutic doses did not show substantial influence on the nervous system. On the indexes of hyperemia and edema of skin and thickness of skin fold of Ferosel $T$ in prophylactic and therapeutic doses at an applique on the skin of crawls did not cause a local irritating action. Separate injection of preparation of «Ferosel T» for $0,1 \mathrm{ml}$ did not cause the filling out reaction of paws guinea-pigs. As a result of undertaken studies it is not educed allergen properties at preparation of «Ferosel T》.

For laboratory rats, Ferosel $T$ was entered that in a prophylactic dose it is not set reliable changes of coefficients of mass of heart, liver, spleen and kidneys. For rats Ferosel $T$ was entered that in an optimal therapeutic dose, in comparing to control mass of spleen and liver was accordingly on 10.3 and $6.4 \%$ anymore. At introduction of Ferosel T to the maximally therapeutic dose mass of spleen and liver was accordingly on 14.0 and $15.0 \%$ anymore.

The got results of researches specify that preparation of Ferosel $T$ is safe at application for a prophylaxis and treatment of animals.

Key words: pharmacology, toxicology, Ferosel T, Iron, Selenium, rat, rabbit, guinea-pigs.

\section{Вступ}

За повідомленнями в літературі, при інтенсивному веденні свинарства на промисловій основі, за відсутності своєчасних профілактичних заходів, захворю- вання новонароджених поросят на ферумдефіцитну анемію складає $100 \%$, а загибель досягає до 35\% (Petrov and Anan'ev, 1982; Todoriuk, 2012). Для лікування і профілактики ферумдефіцитної анемії поросят нами було запропоновано новий феродекстрановий 
препарат «Феросел Т» - аналог офіцинального препарату «Ферровет 7,5\%», від якого феросел Т відрізняється наявністю в ньому селеніту натрію.

Відповідно до постанови Департаменту ветеринарної медицини «Токсикологічний контроль нових засобів захисту тварин», затверджених Головним управлінням ветеринарної медицини Мінсільгосппроду України від 16 грудня 1996 р., кожний новий препарат, що рекомендується для лікування тварин, повинен відповідати таким вимогам:

- новий препарат, у порівнянні 3 препаратоманалогом, повинен проявляти вищу терапевтичну ефективність;

- він повинен бути не токсичним для тварин, яким його застосовують;

- препарат або його метаболіти не повинні впливати на санітарну якість та поживну цінність тваринницької продукції;

- у процесі виробництва та застосування препарат не повинен спричиняти шкоди для довкілля.

Для лікування і профілактики ферумдефіцитної анемії поросят нами запропоновано новий сольовий феродекстрановий препарат «Феросел Т» - аналог офіцинального препарату «Ферровет 7,5\%», від якого феросел Т відрізняється наявністю в ньому натрію селеніту (Todoriuk et al., 2016).

Відповідно до вимог нами проведено експериментальні дослідження щодо вивчення гострої та хронічної токсичностей, фармакологічної дії та фармакотерапевтичної ефективності фероселу Т за спонтанної ферумдефіцитної анемії поросят.

Враховуючи, що токсичність компонентів препарату «Феросел Т», зокрема Феруму і Селену, вже відомі і опубліковані в літературі (Gutyj et al., 2016; Khariv et al., 2016; Martyshuk et al., 2016), ми досліджували гостру та хронічну токсичність препарату «Феросел Т» в цілому, за перорального та парентерального введення, і вивчали його вплив на дезінтоксикаційну функцію печінки.

\section{Матеріал та методи дослідження}

Досліди з визначення гострої токсичності фероселу Т проводили на 50 лабораторних щурах (самцях і самках) масою 270-320 г. За перорального введення досліди проводили на 25 лабораторних білих щурах, які були розділенні на 5 груп по 5 голів у кожній. Дослідним щурам щоденно, 3 доби поспіль, за допомогою металевого зонда через рот вводили феросел Т у профілактичній, терапевтичній, максимально терапевтичній та можливо токсичній дозах (рис. 1). Щурам контрольної групи (5 тварин) щоденно, 3 доби поспіль, у шлунок вводили по 15 мл/кг ізотонічного розчину натрію хлориду.

Досліди 3 визначення гострої токсичності фероселу Т за парентерального введення проводили на 25 лабораторних білих щурах, яких розділили на 5 груп по 5 тварин в кожній. Щурам підшкірно, щоденно 3 доби поспіль вводили феросел Т у профілактичній, терапевтичній, максимально терапевтичній та можливо токсичній дозах.

Після введення препарату спостереження за лабораторними тваринами вели протягом 7 діб. У першу добу досліду тварини знаходились під постійним наглядом. При цьому враховували такі показники: загальний стан, зовнішній вигляд, інтенсивність та характер рухливої активності, координацію рухів, особливості поведінки тварин, наявність судом, реакцію на зовнішні подразники (тактильні, звукові, світлові), стан волосяного покриву i видимих слизових оболонок, відношення до корму, ритм, частоту дихання, час виникнення та характер інтоксикації, іiі важкість, перебіг, час загибелі тварин або їх одужання.

Вплив фероселу $\mathrm{T}$ на детоксикаційну функцію печінки вивчали на 20 білих щурах (самцях і самках) масою 270-320 г. Щурів розділили на 4 групи (по 5 голів у кожній):

щурам першої групи (контрольна) підшкірно вводили ізотонічний розчин натрію хлориду в дозі 6 мл/кг м.т.;

щурам другої групи (Д $)$ підшкірно вводили феросел Т в профілактичній дозі - 1 мл/кг м.т. (75 мг/кг феруму, 0,3 мг/кг селену);

щурам третьої групи (Д2) підшкірно вводили феросел Т в терапевтичній дозі - 2 мл/кг м.т. (150 мг/кг феруму, 0,6 мг/кг селену);

щурам четвертої групи (Д $)$ підшкірно вводили феросел Т в максимальній терапевтичній дозі 6 мл/кг м.т. (450 мг/кг феруму, 1,8 мг/кг селену).

На 31 добу від початку введення препарату на 5 білих щурах $з$ кожної групи провели визначення детоксикуючої функції печінки за допомогою гексеналової проби (Rozin, 1964). Для цього лабораторним тваринам внутрішньоочеревинно вводили $1 \%$ розчин гексеналу в дозі 45 мг/кг. Потім реєстрували середній час сну від моменту коли тварина приймала бокове положення.

Подразнювальну дію фероселу Т на шкіру вивчали на 12 кролях. На спинах тварин виголювали шкіру

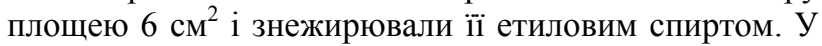
шкіру марлевим тампоном втирали феросел Т в таких дозах: профілактична - 1 мл/кг м.т. (перша група), терапевтична оптимальна - 2 мл/кг (друга група), терапевтична максимальна - 6 мл/кг (третя група). Кролям контрольної груп втирали ізотонічний розчин натрію хлориду в дозі 6 мл/кг. Через 6, 24 і 48 год. після аплікації фероселу Т визначали подразнювальну дію препарату за наявністю (відсутністю) гіперемії і набряку шкіри та за товщиною складки шкіри, яку вимірювали мікрометром. Больову реакцію тварин на препарат визначали при пальпації місця аплікації фероселу $\mathrm{T}$.

Досліди з вивчення алергічних властивостей фероселу Т проводили на морських свинках масою 500560 г. У зв'язку з відсутністю подразнювальної дії фероселу Т випробування алергенних властивостей виконували шляхом виявлення свербежу та набряку у сенсибілізованих цим препаратом тварин.

Морським свинкам $(\mathrm{n}=6)$ дворазово вводили у кон'юнктивальний мішок по 0,05 мл препарату «Феросел Т». Контрольним тваринам $(\mathrm{n}=6)$ вводили стерильний ізотонічний розчин натрію хлориду. Через 12 год. повторно у кон'юнктивальний мішок закапували по 0,05 мл препарату «Феросел Т» (дослід), ізотонічний розчин натрію хлориду (контроль). 
Подразнювальну дію фероселу Т на слизову оболонку ока досліджували на 3 кролях. В кон'юнктивальний мішок лівого ока тварин із піпетки закапували по 2 краплі препарату. Для контролю в праве око тварині закапували по 2 краплі ізотонічного розчину натрію хлориду. Тварину фіксували, відтягували кут кон'юктивального мішка і протягом 1 хв пальцем перетискали слізно-носовий канал. Подразнювальну дію фероселу $\mathrm{T}$ визначали за наявністю (відсутністю) гіперемії кон'юнктиви, ін'єкцією кровоносних судин, станом склери, рогівки, повік.

\section{Результати та їх обговорення}

Встановлення параметрів гострої токсичності npenapamy. Гостра токсичність - це шкідлива дія препарату, що настає після його одноразового або повторного введення через короткі (не менше 4 год.) інтервали протягом доби.

Під час вивчення гострої токсичності препарату «Феросел Т» необхідно було:

- встановити токсичні дози чи побічну дію препарату за одноразового введення орально та парентерально в профілактичній, терапевтичній, максимально терапевничній, можливо токсичній дозах (рис. 1);

- дослідити вплив новоствореного препарату у вказаних дозах на детоксикаційну функцію печінки методом «гексеналової проби».

Параметри гострої токсичності фероселу Т за введення в шлунок білим щурам наведені у табл. 1.

Клінічні спостереження за дослідними і контрольними щурами проводили 7 діб поспіль. За дослідний період у тварин клінічних ознак токсичної дії фероселу Т у досліджуваних нами дозах не встановлено. Загальний стан дослідних тварин був таким, як у контрольних. Поїдання корму і споживання води було в межах норми. Фекалії були без відхилень від нормальної консистенції і запаху. Реакція тварин на звукові і тактильні подразники адекватна. Загибелі тварин не було.

На 7 добу досліду тварин декапітували за легкого ефірного наркозу. На розтині видимих змін у внутрішніх органах не було встановлено.

Отже, препарат «Феросел Т» в профілактичній i терапевтичній дозах та в дозі в 3 рази більшої за терапевтичну, за перорального введення лаборатним щурам 3 доби поспіль не проявляв токсичної дії.

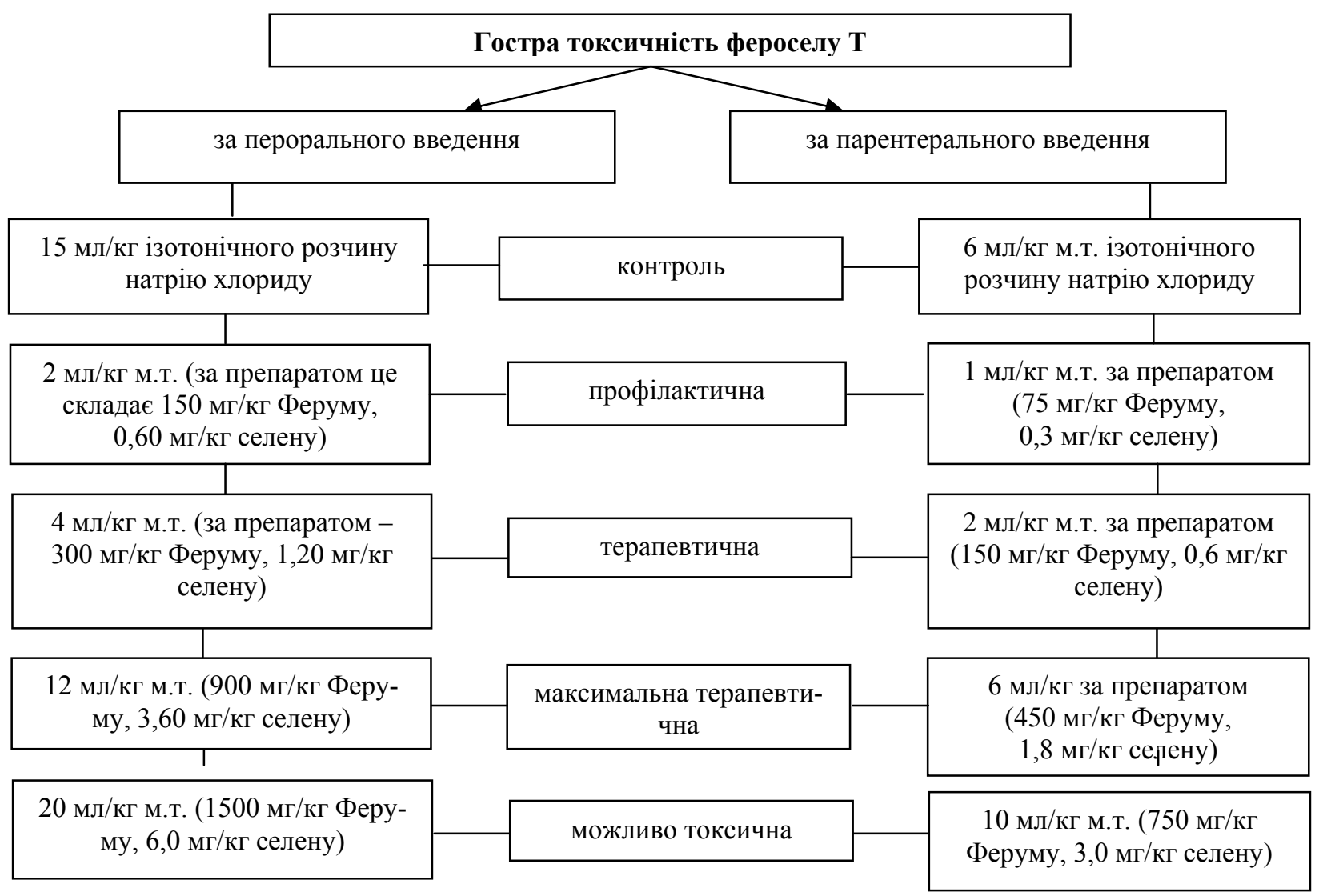

Рис. 1. Дослідження для визначення гострої токсичності

Показники токсичності препарату «Феросел Т» за введення в шлунок білим щурам

\begin{tabular}{|c|c|c|c|c|c|}
\hline \multirow{2}{*}{ Група тварин } & $\begin{array}{c}\text { Кількість тварин у } \\
\text { групі }\end{array}$ & $\begin{array}{c}\text { Доза препарату, } \\
\text { мл/кг }\end{array}$ & всього & у \% \\
\cline { 3 - 6 } & 5 & - & 0 & 0 \\
\hline$Д_{1}$ & 5 & 2 & 0 & 0 & 0 \\
\hline$Д_{2}$ & 5 & 4 & 0 & 0 \\
\hline$Д_{3}$ & 5 & 12 & 0 & 0 \\
\hline$Д_{4}$ & 5 & 20 & 0 & 0 \\
\hline
\end{tabular}


Наступним етапом дослідження було визначення гострої токсичності фероселу Т за парентерального введення лабораторним щурам (табл. 2).

Встановлено, що після підшкірного введення в профілактичній й терапевтичних дозах, навіть у дозі, що в 3 рази перевищує терапевтичну, феросел Т не проявляв токсичної дії на лабораторних щурів. Загальний стан, поїдання корму та реакція на зовнішні подразники у дослідних тварин були такими, як у контрольних.

Таблиия 2

Показники токсичності препарату «Феросел Т» за підшкірного введення білим щурам

\begin{tabular}{|c|c|c|c|c|c|}
\hline Група & \multirow{2}{*}{$\begin{array}{c}\text { Кількість } \\
\text { тварин }\end{array}$} & Доза препарату, & \multicolumn{3}{|c|}{ Число загиблих тварин } \\
\cline { 4 - 6 } & тварин у групі & мл/кг & всього & у \% & середній час загибелі \\
\hline К & 5 & - & 0 & 0 & 0 \\
\hline$Д_{1}$ & 5 & 1 & 0 & 0 & 0 \\
\hline$Д_{2}$ & 5 & 2 & 0 & 0 & 0 \\
\hline$Д_{3}$ & 5 & 6 & 0 & 0 & 0 \\
\hline Д $_{4}$ & 5 & 10 & & 0 & 0 \\
\hline
\end{tabular}

На 7 добу досліду, тварин декапітували за легкого ефірного наркозу. На розтині видимих патологоанатомічних змін у внутрішніх органах не було встановлено. У місцях ін'єкції фероселу Т забарвлення підшкірної клітковини було світло-коричневого кольору, що $\epsilon$ наслідком наявності залишкових кількостей декстрану, який не повністю адсорбувався.

За умов підшкірного введення препарату загибелі білих щурів не було, лише встановлено короткочасне пригнічення лабораторних тварин, яким задавали препарат у дозі 10 мл/кг м.т., що пов'язано з введенням в організм тварин великої кількості препарату, а особливо натрію селеніту (табл. 2).

Отже, в профілактичних, терапевтичних дозах та можливо токсичній за одноразового підшкірного вве- дення протягом 3 діб поспіль феросел Т не спричинив токсичної дії на лабораторних щурів.

Вплив фероселу Т на дезінтоксикаційну функцію печінки. Печінка виконує важливу роль у багатьох видах обміну речовин, синтезі Білка, виконує детоксикаційну і видільну функції. Знешкоджуючи токсичні речовини, клітини печінки стають мішенню їх дії (Gutyj et al., 2017).

Вплив феродекстранових препаратів на антитоксичну функцію печінки вивчали методом гексеналової проби. В основі цього методу лежить здатність різних хімічних речовин впливати на тривалість гексеналового сну у лабораторних тварин, а, як відомо, гексенал повністю метаболізується в печінці.

Тривалість гексеналового сну у білих щурів після введення фероселу T $(\mathbf{M} \pm \mathbf{m} ; \mathbf{n}=5)$

\begin{tabular}{|l|l|c|c|c|}
\hline $\begin{array}{c}\text { Група } \\
\text { тварин }\end{array}$ & \multicolumn{1}{|c|}{$\begin{array}{c}\text { Феросел T } \\
\text { (доза) }\end{array}$} & $\begin{array}{c}\text { Доза Fe } \\
(\text { мг/кг) }\end{array}$ & $\begin{array}{c}\text { Доза Se } \\
\text { (мг/кг) }\end{array}$ & Тривалість сну (хв) за: \\
\hline К & Контрольна & - & - & $27,6 \pm 1,5$ \\
\hline$Д_{1}$ & Профілактична & 75 & 0,3 & $28,2 \pm 1,3$ \\
\hline$Д_{2}$ & Терапевтична оптимальна & 150 & 0,6 & $27,8 \pm 1,5$ \\
\hline$Д_{3}$ & Терапевтична максимальна & 450 & 1,8 & $36,4 \pm 1,4^{*}$ \\
\hline$Д_{4}$ & Можливо токсична & 750 & 3,0 & $37,2 \pm 1,3^{* *}$ \\
\hline
\end{tabular}

Примітка: ступінь вірогідності: ${ }^{*}-\mathrm{P}<0,05 ; * *-\mathrm{P}<0,01$.

Після уведення фероселу Т у вказаних дозах у щурів контрольної і дослідних груп спричиняли фармакологічний сон підшкірним уведенням гексеналу в дозі 60 мг/кг м.т.

Відомо, що тривалість гексеналового сну у тварин залежить від здатності мікросомальних ферментів печінки шляхом глукуронізації нейтралізувати гексенал. Зазвичай у клінічно здорових щурів, за нормального функціонального стану печінки, сон триває 2530 хв.

Тривалість сну тварин відраховували 3 моменту приймання ними бокового положення до перших спроб змінити його, і виражали в хвилинах.

Встановлено, що після підшкірного введення фероселу Т, гексеналовий сон у контрольних і дослідних

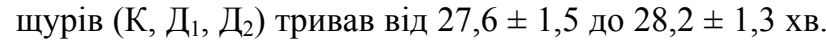
Отже, в профілактичній і оптимальній терапевтичній дозах препарат не впливав на детоксикаційну функцію печінки.

У щурів Д 3 та Д 4 груп, яким феросел Т вводили в максимальній терапевтичній та можливо токсичній дозах, тривалість гексеналового сну була на 32 і 35\% більшою відносно контрольних величин. Вважаємо, що більш тривалий сон став наслідком токсичної дії натрію селеніту на печінку. Селен проявляє гепатотропну дію.

Визначення хронічної токсичності фероселу $T$. Метою визначення хронічної токсичності фероселу Т $\epsilon$ виявлення шкідливої дії препарату у випадках його довготривалого введення в організм дослідних тварин. При цьому має значення виявлення найбільш чутливих його органів і систем, і встановлення зворотного відновлення функцій на тлі дії препарату, що досліджують.

Після повторних введень препарат може проявляти подразнювальну або спричиняти алергічну дії, змінювати функціональний стан репродуктивних органів, впливати на ембріональний розвиток плодів в утробі матері або проявляти тератогенну чи канцерогенну дії.

Токсичність фероселу Т вивчали за показниками подразнювальної дії (за шкірною та кон'юктивальною пробами), алергізуючої дії (метод аплікації на шкіру) 
та визначали коефіцієнти маси внутрішніх органів за тривалого введення препарату.

Упродовж періоду досліджень з визначення хронічної токсичності фероселу Т вірогідних змін у поведінці дослідних тварин не спостерігали (табл. 4).

Апетит усіх щурів дослідних і контрольної групи був задовільним. У тварин, яким вводили феросел Т у дозі 10 мл/кг протягом 21 доби, дещо знижувалася рухова активність. Дослідження емоційноповедінкових реакцій лабораторних тварин після введення фероселу Т протягом 21 доби у терапевтичній та максимально терапевтичній дозах не показало істотного впливу на нервову систему.

Показники фізіологічного стану і активності лабораторних щурів за 21 добового введення фероселу Т $(\mathbf{M} \pm \mathbf{m} ; \mathbf{n}=\mathbf{1 0})$

\begin{tabular}{|c|c|c|c|c|}
\hline $\begin{array}{c}\text { Група } \\
\text { тварин }\end{array}$ & Препарат у дозі & Апетит & $\begin{array}{c}\text { Поведінкова реакція } \\
\text { (кількість нірок, які тварина } \\
\text { обнюхала ) }\end{array}$ & $\begin{array}{c}\text { Вертикальна рухова актив- } \\
\text { ність (число підйомів на } \\
\text { задні кінцівки) }\end{array}$ \\
\hline К & $\begin{array}{c}\text { (ізотонічний розчин } \\
\text { натрію хлориду } \\
6 \text { мл/кг) }\end{array}$ & Задовільний & Нірковий рефлекс збережений & $10,20 \pm 0,51$ \\
\hline$Д_{1}$ & 1 мл/кг & Задовільний & Нірковий рефлекс збережений & $10,65 \pm 0,50$ \\
\hline$Д_{2}$ & 2 мл/кг & Задовільний & Нірковий рефлекс збережений & $10,70 \pm 0,45$ \\
\hline$Д_{3}$ & 6 мл/кг & Задовільний & Нірковий рефлекс збережений & $9,98 \pm 0,60$ \\
\hline$Д_{4}$ & 10 мл/кг & Задовільний & Нірковий рефлекс збережений & $9,57 \pm 0,62$ \\
\hline
\end{tabular}

За цих умов виявлена тенденція до пригнічення у тварин, які отримували феросел Т у дозі 10 мл/кг, що характеризувалося зменшенням рухової активності (кількості пересічених квадратів), реакції оглядання (кількості стоячих поз), грумінгу (кількості умивань). При цьому орієнтовно-дослідна (кількість обнюхувань і заглядань) та емоційна (кількість дефекацій) реакції не відрізнялися як від тварин всіх дослідних груп (Д, , Д 2 , Д 3 та Д 4 ), так і контрольної групи.

Клінічний статус тварин дослідних та контрольної груп у процесі досліду залишався в межах величин фізіологічної норми.

Подразнювальна дія препарату «Феросел T». Встановлено, що за показниками гіперемії і набряку шкіри та товщини шкірної складки феросел Т в профілактичній та терапевтичних дозах при аплікації на шкіру кролів не спричиняв місцевої подразнювальної дії (табл. 5-6).
Таблиця 5

Характеристика місцево-подразнювальної дії препарату «Феросел T», при однократному впливі на шкірні покриви кроликів $(\mathrm{M} \pm \mathbf{m} ; \mathbf{n}=\mathbf{3})$

\begin{tabular}{|c|c|c|c|c|}
\hline $\begin{array}{c}\text { Щільність } \\
\text { нанесения, } \\
\text { мл/см }\end{array}$ & \multicolumn{5}{|c|}{ Середній бал вираженості } \\
\cline { 2 - 5 } & Група 1 & Група 2 & Група 3 & Група 4 \\
\hline \multicolumn{5}{|c|}{ набряки } \\
\hline 0,020 & 0 & 0 & 0 & 0 \\
\hline 0,040 & 0 & 0 & 0 & 0 \\
\hline 0,060 & 0 & 0 & 0 & 0 \\
\hline 0,080 & 0 & 0 & 0 & 0 \\
\hline 0,100 & 0 & 0 & 0 & 0 \\
\hline 0,120 & 0 & 0 & 0 & 0 \\
\hline \multicolumn{5}{|c|}{ еритеми } \\
\hline 0,020 & 0 & 0 & 0 & 0 \\
\hline 0,040 & 0 & 0 & 0 & 0 \\
\hline 0,060 & 0 & 0 & 0 & 0 \\
\hline 0,080 & 0 & 0 & 0 & 0 \\
\hline 0,100 & 0 & 0 & 0 & 0 \\
\hline 0,120 & 0 & 0 & 0 & 0 \\
\hline
\end{tabular}

Товщина складки шкіри кролів після аплікації фероселу Т (M \pm m; n=3)

Таблиия 6

\begin{tabular}{|c|c|c|c|c|}
\hline \multirow{2}{*}{ № $3 /$ п } & \multirow{2}{*}{$\begin{array}{c}\text { Група тварин, } \\
\text { феросел Т (доза) }\end{array}$} & \multicolumn{3}{|c|}{ Товщина складки шкіри, мм } \\
\hline & & 6 год & 24 год & 48 год \\
\hline 1 & $\begin{array}{l}\text { Контрольна }(\text { К) }-6 \text { мл/кг м.т. } \\
\text { (ізотонічного розчину натрію хлориду) }\end{array}$ & $2,04 \pm 0,03$ & $2,06 \pm 0,05$ & $2,07 \pm 0,04$ \\
\hline 2 & $\begin{array}{l}\text { Профілактична (Д) } \\
\text { 1мл/кг м.т. }\end{array}$ & $2,08 \pm 0,03$ & $2,08 \pm 0,03$ & $2,07 \pm 0,05$ \\
\hline 3 & $\begin{array}{l}\text { Терапевтична оптимальна }\left(Д_{2}\right) \\
2 \text { мл/кг м.т. }\end{array}$ & $2,06 \pm 0,02$ & $2,06 \pm 0,03$ & $2,05 \pm 0,04$ \\
\hline 4 & $\begin{array}{l}\text { Терапевтична максимальна (Д }) \\
6 \text { мл/кг м.т. }\end{array}$ & $2,03 \pm 0,05$ & $2,05 \pm 0,03$ & $2,06 \pm 0,04$ \\
\hline 5 & $\begin{array}{l}\text { Можливо токсична }\left(Д_{4}\right) \\
10 \text { мл/кг м.т. }\end{array}$ & $2,05 \pm 0,04$ & $2,07 \pm 0,03$ & $2,06 \pm 0,03$ \\
\hline
\end{tabular}


При дослідженні реакції кон'юнктиви на феросел Т, через 30 хв, 1, 3, 6, 12, 24 і 48 год. після інстиляції препарату за досліджуваними нами показниками не встановлено подразнювальної дії фероселу Т (табл. 7).

Вплив препарату «Феросел Т» на кон'юнктиви, рогівки і повіки очей кролика $(\mathrm{M} \pm \mathbf{m} ; \mathbf{n}=3)$

\begin{tabular}{|c|c|c|c|c|c|c|}
\hline \multirow{2}{*}{ Час досліду } & \multicolumn{2}{|c|}{ Кролики групи № 1 } & \multicolumn{2}{|c|}{ Кролики групи № 2 } & \multicolumn{2}{|c|}{ Кролики групи № 3} \\
\cline { 2 - 7 } & балах в & $\begin{array}{c}\text { Подразню-вальний } \\
\text { ефект }\end{array}$ & $\begin{array}{c}\text { Оцінка в } \\
\text { балах }\end{array}$ & $\begin{array}{c}\text { Подразню-вальний } \\
\text { ефект }\end{array}$ & $\begin{array}{c}\text { Оцінка в } \\
\text { балах }\end{array}$ & $\begin{array}{c}\text { Подразню-вальний } \\
\text { ефект }\end{array}$ \\
\hline До введения & 0 & Відсутній & 0 & Відсутній & 0 & Відсутній \\
\hline Через 30 хв. & 0 & Відсутній & 0 & Відсутній & 0 & Відсутній \\
\hline Через 1 год. & 0 & Відсутній & 0 & Відсутній & 0 & Відсутній \\
\hline Через 3 год. & 0 & Відсутній & 0 & Відсутній & 0 & Відсутній \\
\hline Через 6 год. & 0 & Відсутній & 0 & Відсутній & 0 & Відсутній \\
\hline Через 12 год. & 0 & Відсутній & 0 & Відсутній & 0 & Відсутній \\
\hline Через 24 год. & 0 & Відсутній & 0 & Відсутній & 0 & Відсутній \\
\hline Через 48 год. & 0 & Відсутній & 0 & Відсутній & 0 & Відсутній \\
\hline
\end{tabular}

Отже, препарат «Феросел Т» не володіє подразнювальми властивостями при зовнішньому застосуванні.

Алергенні властивості препарату «Феросел T». Роздільна ін'єкція препарату «Феросел Т» субплантарно морським свинкам $(\mathrm{n}=6)$ по 0,1 мл не викликала набряклої реакції лап, що відрізняється від аналогічної реакції на введення ізотонічного розчину натрію хлориду $(\mathrm{n}=6)$ (табл. 8).

Частота виявлення гіперчутливості у морських свинок після внутрішньошкірного введення фероселу Т по кон'юнктивальному тесту і набряку $(\mathrm{n}=6)$

\begin{tabular}{|c|c|c|c|}
\hline \multirow{2}{*}{ Групи } & \multicolumn{3}{|c|}{ Кон’юнктивальний тест } \\
\cline { 2 - 4 } & 0 & Через 1 год. & Через 24 год. \\
\hline Феросел Т & $6 / 6$ & $0 / 6$ & $0 / 6$ \\
\hline $\begin{array}{c}\text { Ізотонічний розчин } \\
\text { Натрію Хлориду }\end{array}$ & $6 / 6$ & $0 / 6$ & $0 / 6$ \\
\hline & \multicolumn{3}{|c|}{ Набряк лап } \\
\hline Феросел Т & $0 / 6$ & $6 / 6$ & $0 / 6$ \\
\hline $\begin{array}{c}\text { Ізотонічний розчин } \\
\text { Натрію Хлориду }\end{array}$ & $0 / 6$ & $6 / 6$ & $0 / 6$ \\
\hline
\end{tabular}

У результаті проведених досліджень не виявлено алергенних властивостей у препарата «Феросел Т».
Дослід показав відсутність реакції кон'юнктиви сенсибілізованих і інтактних морських свинок через 1 i 24 години на інстиляцію препарату (табл. 8).

Вплив фероселу Т на коефіцієнти маси внутрішніх органів. Досліди провели на 25 лабораторних щурах масою 270-320 г. Протягом 30 діб тваринам підшкірно вводили феросел Т з інтервалом 7 діб (4 ін'єкції) в таких дозах: профілактична - 1 мл/кг м.т., терапевтична оптимальна - 2 мл/кг; терапевтична максимальна - 6 мл/кг, можливо токсична - 10 мл/кг. Щурам контрольної групи, з інтервалом 7 діб, підшкірно вводили ізотонічний розчин натрію хлориду в дозі 6 мл/кг.

Протягом досліду за тваринами проводили клінічні спостереження. На 30 добу тварин декапітували під легким ефірним наркозом і визначали коефіцієнти маси внутрішніх органів (табл. 9).

У лабораторних щурів, яким вводили феросел Т в профілактичній дозі, у порівнянні 3 контрольними вірогідних змін коефіцієнтів маси серця, печінки, селезінки і нирок не встановлено.

У щурів, яким вводили феросел Т в оптимальній терапевтичній дозі, у порівнянні з контрольними маса селезінки і печінки була відповідно на 10,3 і 6,4\% більшою. При введенні фероселу Т у максимально терапевтичній дозі маса селезінки і печінки була відповідно на 14,0 і 15,0\% більшою

Таблиия 9

Коефіціснти маси внутрішніх органів лабораторних щурів після введення фероселу T $(\mathbf{M} \pm \mathbf{m} ; \mathbf{n}=5)$

\begin{tabular}{|c|c|c|c|c|c|}
\hline \multirow{2}{*}{$\begin{array}{l}\text { № } \\
3 / \Pi\end{array}$} & \multirow{2}{*}{$\begin{array}{c}\text { Група тварин } \\
\text { феросел Т (доза) }\end{array}$} & \multicolumn{3}{|c|}{ Маса внутрішніх органів (г) } \\
\cline { 3 - 6 } & Серце & Селезінка & Печінка & Нирки \\
\hline 1 & Контрольна & $3,80 \pm 0,18$ & $3,30 \pm 0,15$ & $30,20 \pm 1,0$ & $7,34 \pm 0,25$ \\
\hline 2 & $\begin{array}{c}\text { Профілактична, } \\
1 \text { мл/кг }\end{array}$ & $3,76 \pm 0,10$ & $3,35 \pm 0,13$ & $30,15 \pm 1,1$ & $7,36 \pm 0,30$ \\
\hline 3 & $\begin{array}{c}\text { Терапевтична оптима- } \\
\text { льна, 2 мл/кг }\end{array}$ & $3,78 \pm 0,15$ & $3,64 \pm 0,10^{* *}$ & $32,13 \pm 1,2$ & $7,32 \pm 0,20$ \\
\hline 4 & $\begin{array}{c}\text { Терапевтична } \\
\text { максимальна, 6 мл/кг }\end{array}$ & $3,76 \pm 0,11$ & $3,76 \pm 0,16^{*}$ & $34,75 \pm 1,0 * *$ & $7,28 \pm 0,22$ \\
\hline 5 & $\begin{array}{c}\text { Можливо токсична, } \\
10 \text { мл/кг }\end{array}$ & $3,75 \pm 0,10$ & $3,81 \pm 0,12^{*}$ & $35,14 \pm 1,1 * *$ & $7,21 \pm 0,21$ \\
\hline
\end{tabular}

Примітка: ступінь вірогідності по відношенню до контролю: *-P<0,05, ** $-P<0,01$.

Scientific Messenger LNUVMBT named after S.Z. Gzhytskyj, 2017, vol. 19, no 73 
Коефіцієнти маси серця і нирок у щурів другої і третьої груп не вказували вірогідної різниці по відношенню до контролю. Вважаємо, що після тривалого введення щурам фероселу Т в терапевтичних дозах (оптимальній, максимальній i можливо токсичній) збільшення маси печінки і селезінки відбулося внаслідок посилення функціонального стану цих органів та припливу до них крові.

\section{Висновки}

За перорального введення фероселу Т в профілактичній дозі 2 мл/кг м.т. (що складає Феруму 150 мг/кг, Селену - 0,6 мг/кг) та терапевтичній дозі 4 мл/кг (Феруму - 300,0 мг/кг, Селену - 1,2 мг/кг) за введення 3 доби поспіль в шлунок лабораторним щурам токсична дія не проявляється. Не встановлено токсичної дії фероселу Т також за введення його в шлунок в дозах в 3 і 10 раз більших за терапевтичну;

За підшкірного введення фероселу Т 3 доби поспіль в профілактичній дозі, оптимальній терапевтичній, максимальній терапевтичній та в дозі в 5 раз більшій за терапевтичну препарат не спричиняв токсичної дії на лабораторних щурів;

У дослідах із визначення гексеналового сну встановлено, що у профілактичній і оптимальній терапевтичних дозах феросел Т не впливав на дезінтоксикаційну функцію печінки. В терапевтичній максимальній дозі препарат у перші 6 год. після введення незначно знижував дезінтоксикаційну функцію печінки за рахунок натрію селеніту, який в дозі 1,2 мг/кг проявляє гепатотропну дію. Через 24 год. після введення фероселу Т детоксикаційна функція печінки спонтанно повністю відновилася.

При вивченні хронічної токсичності встановлено, що феросел Т не діє подразнювально на шкіру і слизові оболонки та не проявляє алергізуючого ефекту на організм тварин після багаторазової аплікації;

В оптимальній і максимальній терапевтичній дозах феросел Т на 14\% збільшував масу селезінки, що відбувалося внаслідок активації в ній процесів еритропоезу та на 15\% підвищував масу печінки внаслідок посилення в ній Білоксинтезувальної функції. Поряд з цим, внаслідок посилення функціонального стану вказаних органів, відбувається приплив крові, що також збільшує масу внутрішніх органів;

За класифікацією токсичних речовин (ДОСТ 12.1.007-76), за ступенем небезпечності для тварин феросел Т в цілому та його компонент - феруму сульфат відноситься до 4 класу токсичності (малотоксичні речовини). Другий компонент фероселу Т - натрію селеніт відноситься до 4 класу токсичності (помірно токсичні речовини).

\section{Бібліографічні посилання}

Petrov, V.M., Anan'ev, P.K. (1982). Profilaktika zabolevanij molodnjaka sel's'kohozjajstvennyh zhivotnyh v promyshlennyh kompleksah. Alma-Ata: Bagration, 50-64 (in Russian).

Toksykolohichnyi kontrol novykh zasobiv zakhystu tvaryn (Metodychni rekomendatsii) (1996). Holovnym upravlinniam veterynarnoi medytsyny Min. Silhospprodu Ukrainy. Kyiv, 33 (in Ukrainian).

Gutyj, B., Paska, M., Levkivska, N., Pelenyo, R., Nazaruk, N., Guta, Z. (2016). Study of acute and chronic toxicity of 'injectable mevesel' investigational drug. Biological Bulletin of Bogdan Chmelnitskiy Melitopol State Pedagogical University. 6(2), 174180. doi: http://dx.doi.org/10.15421/201649

Gutyj, B., Khariv, I., Binkevych, V., Binkevych, O., Levkivska, N., Levkivskyj, D., Vavrysevich, Y. (2017). Research on acute and chronic toxity of the experimental drug Amprolinsyl. Regul. Mech. Biosyst. 8(1), 41-45.

Khariv, M., Gutyj, B., Butsyak, V., Khariv, I. (2016). Hematological indices of rat organisms under conditions of oxidative stress and liposomal preparation action. Biological Bulletin of Bogdan Chmelnitskiy Melitopol State Pedagogical University. 6 (1), 276-289. doi: http://dx.doi.org/10.15421/201615

Martyshuk, T.V., Gutyj, B.V., Vishchur, O.I. (2016). Level of lipid peroxidation products in the blood of rats under the influence of oxidative stress and under the action of liposomal preparation of «Butaselmevit», Biological Bulletin of Bogdan Chmelnitskiy Melitopol State Pedagogical University. 6(2), 22-27. doi: http://dx.doi.org/10.15421/201631

Todoriuk, V.B. (2012). Vplyw preparatu Minbivitu na profilacticu anernii porosat [Influence of Minbevit on the prevention of anemia of piglets]. Nauc. Visnic LNUVMBT - Research Bulletin LNUVMIBT. 14, 3(53), 273-278 (in Ukrainian).

Todoriuk, V.B., Gutyj, B.V., Khomyk, R.I., Vasiv, R.O. (2016). Influence of ferrovet $7.5 \%$ and ferosel $T$ on the concentration of mineral substances in the blood serum of piglets suffering from Iron deficit anemia. Scientific Messenger LNUVMBT named after S.Z. Gzhytskyj. 18, 3(71), 139-143.

Rozin, D.G. (1964). Modern evaluation of toxicity chlorproductive carbohydrates of fatty raw yder gexanal test with white mice. Pharmacology and toxicology. 5, 613-614.

Стаття надійшла до редакиії 4.03.2017 